\title{
The Practices and Effectiveness of Internal Auditing among Public Higher Education Institutions, Ethiopia
}

\author{
Tadesse Demeke $^{1 *}$, Jasmindeep Kaur ${ }^{2}$, Rajeev Kansal ${ }^{2}$ \\ ${ }^{1}$ Department of Accounting and Finance, College of Business and Economics, Dire Dawa University, Dire Dawa, Ethiopia \\ ${ }^{2}$ Department of Commerce, Faculty of Business Studies, Punjabi University, Patiala, India \\ Email: *tadessedemeke22@gmail.com,bhnoor@yahoo.co.in,drkansal@gmail.com
}

How to cite this paper: Demeke, T., Kaur, J., \& Kansal, R. (2020). The Practices and Effectiveness of Internal Auditing among Public Higher Education Institutions, Ethiopia. American Journal of Industrial and Business Management, 10, 1291-1315. https://doi.org/10.4236/ajibm.2020.107086

Received: June 28, 2020

Accepted: July 25, 2020

Published: July 28, 2020

Copyright $\odot 2020$ by author(s) and Scientific Research Publishing Inc. This work is licensed under the Creative Commons Attribution International License (CC BY 4.0).

http://creativecommons.org/licenses/by/4.0/

\begin{abstract}
The existence of multi-dimensional measures of internal audit effectiveness, and the findings of most prior studies are not consistent. As a result of this, to add knowledge to the existing literature and to give direction to the institutions, the study focused on the comparison of the practices and effectiveness of internal auditing among public higher education institutions in Ethiopia. With regards to the sampling techniques employed towards achieving the objective of the study, proportional stratified random sampling, purposive sampling and census were used for the selection of sample institutions, the relevant department and the appropriate respondents respectively. Following this, a total of one hundred sixty (160) questionnaires were distributed to the internal auditors of the sampled institutions out of which one hundred twenty-one (121) questionnaires were effective. The internal auditors were picked from eighteen sample universities out of the 30 target universities. The respondents were considered based on their direct attachment to the study area. By using analysis of moment structures (AMOS), the confirmatory factor analysis was used to identify a set of items which are strongly related to the variables. The Chi-Square test was applied to analyze the data. Top management support, organizational independence, adequate and competent internal auditors, internal audit charter, quality of internal audit work, career and advancement, management perception of internal audit function value, information technology, and objectivity of internal auditors were used as the proxy measures of internal auditing practices, whereas auditees' evaluation, added contribution of internal audit, and auditing quality were used as the proxy measures of internal audit effectiveness. Out of these 12 variables employed in the confirmatory factor analysis, only 9 variables (top management support, organizational independence, adequate and competent internal auditors, internal audit charter, quality of internal audit work, information tech-
\end{abstract}


nology, objectivity of internal auditors, auditees' evaluation, and auditing quality) were supported for further analysis. The findings of the study signified that, statistically, there was no significant difference in internal auditing practices and effectiveness among the public higher education institutions. The following could be the reasons for this insignificant difference: first, most public higher education institutions in Ethiopia are similar in policies, procedures, organizational contexts, rules and regulations, and organizational structure; and second, all the public higher education institutions share the same internal audit manual. It can be concluded that the use of electronic technology or modern auditing system instead of traditional auditing systems will improve the auditing activities of the institutions.

\section{Keywords}

Ethiopian Public Higher Education Institutions, Information Technology, Effectiveness of Internal Auditing, Practices of Internal Auditing

\section{Introduction}

Recently, internal auditing practice is being recognized as one of the major determinants of effective and efficient utilization of resources in organizations all over the world. The recent corporate failure (Pickett, 2010), the wastage of public resources and the rapid growth of professional institutions are the major contributors towards the increased current demand of internal auditing in different countries (Cohen \& Sayag, 2010). Internal auditing is an independent, objective assurance and consulting activity designed to add value and improve an organization's operations. Also, it is a catalyst to improve an organization's governance, risk management and management controls by providing insight and recommendations based on analyses and assessments of data and business processes (Institute of Internal Auditors, 2004; Pickett, 2005; Paape, 2007; Pickett, 2010; Al-Khaddash et al., 2013). Internal auditor is the only employee within an organization who has a deep understanding about the risk and its control mechanism. That is, internal audit has more advantage than the external audit in obtaining information quickly and identifying problems at an earlier stage. Internal auditors also provide advice of risk management and control to the relevant staffs, and provide independent and objective assurance to the board about the adequacy and effectiveness of the key controls and other risk management activities across the institutions (IIA, 2001; Pickett, 2005; Pickett, 2010; Institute of Internal Auditors, 2012). Moreover, the demand of auditing in the economy is unquestionable (Arens et al., 2012); i.e. internal auditors play a great role in the economy by providing suggestions on the financial statements whether the financial reports represent fair and accurate information. This suggestion is important for the users of financial statements to gain assurance that the data that are being reported are relevant, unbiased and accurate to make their appropriate decision (Paape, 2007; Al-Khaddash et al., 2013; Al-Matari et al., 
2014; Baharud-din et al., 2014). For instance, as it is known, the primary factors that affect the loan interest rate are the combination of the three, i.e. risk-free interest rate, business risk and information risk. Risk-free interest rate is the interest rate earned by a business if it invests in governmental securities such as in Treasury bill. Business risk is the probability that the business will not be able to repay its loan because of economic or business conditions. Information risk is the probability of giving inaccurate information to users or decision makers. Although internal auditing doesn't have a significant effect on risk-free rate and business risk, it has a significant effect on information risk, because auditing provides assurance services to users that the financial statements are reliable. This assurance service reduces information risk (lender risk); i.e. overall interest rate of the borrower or the business will be decreased. On the other hand, the borrower or the business can get capital at a reasonable cost (Arens et al., 2012).

In addition to the above general overview of internal auditing, some internal audit studies have been conducted on the basis of neoclassical economic theories such as agency theory (Adams, 1994) and transaction cost theory (Spraakman, 1997). The assumptions of neoclassical economic theories make some limits in the application of the theories (Mihret, 2010), i.e. they assume developed market economic setting and large volume of transactions (Asechemie, 1997 as cited in Mihret, 2010), the concept of market equilibrium (Mihret, 2010) and organizational phenomenon (the result of individuals to maximize their self-interest) (Mihret, 2010). Because of these, neoclassical economic theories may not sufficiently describe the internal audit development and operation in developing countries like Ethiopia (Mihret, 2010). The institutional theory explains how institutional practices and structures are shaped through changes, which come by both internal and external pressures such as by regulations and laws, by taking the practices of other institutions and by recognition of professions. DiMaggio and Powell (1983) described the isomorphism process of institutional theory in three ways, i.e. coercive, mimetic and normative isomorphism. Coercive isomorphism happens as a result of institutional attempts for legitimacy. Mimetic isomorphism takes place when organizations respond to uncertainty by emulating the practices of other institutions. Normative isomorphism takes place when institutional changes happen due to organizations "recognition of professions. In addition, institutional theory recommended making study at different stages of units of analysis, such as industries, individual organizations or other collectives (Barley \& Tolbert, 1997). The theory is also recommended in the internal audit study because it is possible to employ without limiting the scope to profit-oriented institutions and developed market economy (Mihret, 2010). This study was therefore conducted with this understanding on the basis of the institutional theory by taking into account top management support, organizational independence, professional proficiency, internal audit charter, quality of internal audit work, management perception of internal audit function value, career and advancement, information technology and objectivity of internal auditors as proxy measures of in- 
ternal auditing practices, whereas auditees' evaluation, added contribution of internal audit, and auditing quality as proxy measures of internal audit effectiveness.

\section{Review of Literature}

As a result of the legal and cultural environment, purpose, structure, size, as well as by person within and outside the organization, the findings of most prior studies are not consistent. Although there is difficult to get prior studies that are directly related to the study, the summary of some related studies are presented as follows.

Institute of Internal Auditors (2001) is the setter of the International Standards for the Professional Practice of Internal Auditing. In accordance with the Institute of Internal auditors, self-review, social pressure, personal relationship, cultural, cognitive, and economic interests like gifts from employees, clients, and business associates are the main causes for the bias of internal auditors. Further, the Institute of Internal Auditors recommended that to ensure the independence of internal auditors, the audit department of institution functionally it should report to the audit committee or board of directors, and administratively to the chief executive officer of the institution. In addition, the institute concluded that to get quick information and to find problems at an earlier stage, internal auditors had more advantage than external auditors.

Mihret and Yismaw (2007) assessed internal audit effectiveness in the Ethiopian public sector by collecting data from 14 internal auditors in addition to review document. In accordance with the study, internal audit effectiveness was measured by organizational setting (defined by organizational profile, internal organization, organizational policies and procedures, and internal audit budget), internal audit quality (defined by staff expertise, scope of internal audit, audit plan, fieldwork and controlling, and effective communication), management support (defined by response to the audit findings, and commitment to strengthen internal audit), and auditee attributes (defined by auditee' proficiency, auditee attitude, and cooperation). The findings of their study indicated that internal audit quality and management support were the major factors for the success of internal audit function, but the organizational setting and auditee attributes were not as such. Although internal audit plays a major role in the success of every organization, the management of the institutions do not give an adequate response to the internal audit findings and recommendations.

Abu-Musa (2008) investigated the impact of information technology on the internal audit activities in Saudi organizations after collecting data from 218 internal auditors. The findings of the study indicated that the internal auditors' knowledge and skills related to computerized information systems for the purpose of planning, supervising, directing and reviewing the work performed should be improved.

Cohen and Sayag (2010) investigated the determinants of internal audit effectiveness in Israeli organizations, and the data were collected from 108 respondents that comprised both internal auditors and general managers. Sector 
(private versus public), professional proficiency of internal auditors, quality of audit work, organizational independence, career and advancement, and top management support were included under independent variables, whereas internal audit effectiveness was included under dependent variables, which is measured by auditees' evaluation, auditing quality, and added contribution of internal audit. Their findings revealed that top management support had a significant and positive effect regardless of whether the organization was private or public on the three internal audit effectiveness dimensions, i.e. auditing quality, auditees' evaluation and added contribution of internal audit. But organizational independence had a positive and significant effect only related to auditees' evaluation. On the other hand, they concluded that all other determinants of internal audit effectiveness, i.e. professional proficiency of internal auditors, quality of audit work, career and advancement, including organizational independence were the results of top management decisions. That is, the support of top management is a crucial for the success and operation of internal audit within the institution through hiring trained and experienced staffs, and providing sufficient resources.

Mihret (2010) investigated antecedents and organizational performance implication of internal audit effectiveness in Ethiopian Governmental ministries, state-owned enterprises and private companies, and the data were collected from 188 respondents that comprised internal auditors, middle managers and Institute of Internal Auditors-Ethiopian leaders in addition to archival sources. The aims of the study were to test the influence of contextual factors on internal audit effectiveness and to explore the association between internal audit effectiveness and company performance (measured by Return on Asset). In accordance with the study, contextual factor was measured by country-level factors (economic setting and political ideology, government support, and accounting and auditing development level) and organizational-level factors (organizational category, organizational size, organizational risk exposure, organizational policies authorizing, auditee cooperation and internal-external audit linkages). Also, internal audit effectiveness was measured by professional proficiency of internal auditors', internal auditors' independence and objectivity, scope of internal audit work, quality of internal audit planning and execution, quality of internal audit report, and follow up of audit recommendations. The findings of the study revealed that the country-level contextual factors had significant contribution for the development of internal auditing through coercive isomorphic pressures. From organizational-level contextual factors point of view, the findings of the study showed that internal audit effectiveness was significantly associated with organization-level contextual factors. Moreover, the findings of the study indicated that internal audit effectiveness had not significant association with the company performance.

Al-Refaee and Siam (2013) assessed the effect of information technology on the efficiency of internal auditing systems in Jordan Islamic Banks, and the data were collected from 48 internal auditors. The study took operational control 
risk, and independence and privacy of internal auditors' as the proxy measures of the efficiency of internal auditing systems, whereas information technology was taken as the independent variable. The study findings indicated that the information technology had a positive and material effect on both operational control risk and independence and privacy of internal auditors. On the basis of the findings of the study, they provided evidence that information technology is better than the manual system related to accuracy, clarity, and speed of management reports. Moreover, based on the findings, the study supplied the following recommendations for the Jordan Islamic Banks: First, managing first-time banking operations between the internal audit department and management, second, the audit department should control all aspects of the banking activities, and third, preparing computer-oriented auditing activities seminars.

Al-Matari et al. (2014) examined the effect of professional proficiency of chief audit executives, size of internal auditors, experience of internal auditors and qualification of internal auditors' on firm performance in Malaysia organizations. Their findings revealed that an efficient internal audit department was important for the improvement of the organizations' performance because financial reports of the company indicate the quality of the internal audit department. Also, the study indicated the internal audit department as it's very important in the firm where an accounting system is employed. Additionally, the study explained that the internal audit department is an essential part of corporate governance structure in the institutions because corporate governance includes the activities conducted by the audit committees and the board of directors.

Sakour and Laila (2015) investigated the association between internal audit effectiveness and the four factors linked with International Standards for Professional Practice of Internal Auditing, i.e. independence, work performance, competence and scope of work. The study also used internal auditors' pay satisfaction as a mediator variable to check the association between these four factors and internal audit effectiveness. Based on the review literature, the study concluded that the pay satisfaction of internal auditors' was one of the most significant variables for the internal audit effectiveness. Finally, the study recommended further empirical researches to investigate the association between internal audit effectiveness and the four variables (independence, work performance, competence and scope of work), and also it recommended to include internal auditors' pay satisfaction as a mediator variable.

Generally, based on the review of the literature, first, as the best of the researchers' knowledge, studies have not been conducted directly related to the objective of this study, second, very few prior studies used the three dimensions as the proxy measures of internal audit effectiveness, i.e. auditees' evaluation, added contribution of internal audit, and auditing quality. On the other hand, in this study, these three dimensions were used as the proxy measures of internal audit effectiveness in addition to the input approach, Because of these, understanding the practices and the effectiveness of internal auditing at a global level 
yet not complete. With this understanding, studies to examine the practices and the effectiveness of internal auditing among institutions from theoretical perspectives in diverse empirical settings become necessary. This would enable the profession to get orientation at the global level and play an important role in the public and business sectors. This study was therefore conducted on the practices and effectiveness of internal auditing among public higher education institutions in Ethiopia.

\section{Materials and Methods}

\subsection{Description of the Study Area}

The study is conducted in public higher education institutions of Ethiopia. Higher education training in Ethiopia was started over fifty years ago, but still, it is immature. One of the basic reasons for the immature of the higher education institutions was the political instability of the country (Fekadu, 2009). Similarly, as a World Bank report in the $20^{\text {th }}$ century indicates because of humanitarian crises, armed conflict, and famine, Ethiopia was one of the disadvantaged countries in the world in terms of education (Trines, 2018). Haile Selassie University was the first higher public education institution in Ethiopia that was established in 1961, and in 1974 it is name was changed to Addis Ababa University (AAU). After 1991, the number of public universities is increasing. That is, in 1991 there were four (4) public universities in Ethiopia, including the University of Asmara which was part of Ethiopia before Eritrea got its independence from Ethiopia. In 2001 the number of public universities increased to eight (8), which is a $100 \%$ increase as compared to the year 1991. The number of public universities in the country in the year 2011 increased by $175 \%$ as compared to the year 2001, which means that it has increased to twenty-two (22). But in 2018, (the year in which the data for this study were collected), there were forty-five (45) public universities in the country (Ethiopian News Agency Report, n.d. as cited in https://www.awrambatimes.com/?p=13861; Trines, 2018).

\subsection{Definition of Measure of Internal Auditing Practices}

Top Management Support: Hung and Han (1998) had defined that top management support was the attitude of management toward the internal audit findings and opinions, and the importance of internal auditing from a management point of view. The concept of top management support refers to the response of management for the audit findings and its commitment to implement the internal audit recommendations (Mihret \& Yismaw, 2007; Fekadu, 2009; Cohen \& Sayag, 2010). According to Al-Khaddash et al. (2013), top management support was incentives like competitive fees, rewards, bounces, etc. which are giving by the management to encourage internal auditors. In addition, Ebissa (2015) had defined the concept of top management support in terms of resources like finance, transport, training, new technology, and so on, which are supporting by the management to do the internal audit function in a proper way.

Organizational independence: Organizational independence refers to the 
concept of being free from any management influence like data access, budget, and audit timing while internal auditors perform their audit activities and issue audit reports (Mihret \& Yismaw, 2007; Cohen \& Sayag, 2010; Ebissa, 2015; Dellai \& Omri, 2016).

Adequate and competent internal auditors: The concept of adequate and competent internal auditors was measured by the size, educational level, training and development programs, professional certificates and experience of internal auditors (Haron et al., 2004; Mihret \& Yismaw, 2007; Cohen \& Sayag, 2010; Deribe \& Regasa, 2014; Ebissa, 2015).

Internal audit charter: The concept of internal audit charter refers to a formal written document, which contains the scope, purpose, authority, and responsibility of internal auditors in the institution (IIA, 2001; Ebissa, 2015).

Quality of internal audit work: The concept of quality of internal audit work refers to the accuracy and adequacy of audit programs, the scope of service (Haron et al., 2004; Mihret \& Yismaw, 2007; Deribe \& Regasa, 2014), fieldwork, quality review, internal audits communication (Mihret \& Yismaw, 2007), effective annual audit plan (Mihret \& Yismaw, 2007; Cohen \& Sayag, 2010), and follow-up procedure (Cohen \& Sayag, 2010).

Career and advancement: As clearly stated by Hung and Han (1998), Goodwin and Yeo (2000), Cohen and Sayag (2010), and Dellai and Omri (2016), the concept of career and advancement refers to hiring and assigning employees for temporary as an internal auditor to transfer them to a better position (usually to management position) in the near future.

Management perception of internal audit function value: Management perception of internal audit function value is management awareness or understanding about the roles of internal auditors in the institution (Ebissa, 2015).

Information Technology: The concept of information technology indicates the availability of software packages like planning software to run the audit function of the institution (Deribe \& Regasa, 2014).

Objectivity of internal auditors: The concept of objectivity of internal auditors refers to the unbiased mental attitude of internal auditors when carrying out their audit duties. That is, not participating in an audit of activities for the operation of which they were responsible previously until a reasonable time has elapsed, rotating their assignments, and they must be free from social pressure, economic advantage, and political influence, when performing their audit duties (Institute of Internal Auditors, 2001).

\subsection{Definition of Measure of Internal Audit Effectiveness}

The literature advocates the difficulty of measuring internal audit effectiveness and the absence of a commonly agreed approach for measurement. Fadzil and Hanim (2003) had measured internal audit effectiveness by using the external audit fee, which is more recommended for profit-oriented institutions. Mihret and Yismaw (2007), and Mihret (2010) have used the input approach (compli- 
ance with SPPIA) to measure internal audit effectiveness. Mihret and Yismaw (2007), and Mihret and Woldeyohannis (2008) had measured internal audit effectiveness by using the number of audits conducted in a particular year. Mihret and Woldeyohannis (2008) had defined internal audit effectiveness by using the level of implementation of internal audit recommendations. Cohen and Sayag (2010) have used the output approach to measure internal audit effectiveness. That is, in accordance with the output approach, internal audit effectiveness is measured by three dimensions, i.e. auditees' evaluation, added contribution of internal audit, and auditing quality. Ebissa (2015) has used internal auditors completeness in identifying non-compliance activities and added contribution of internal audit as a measurement of internal audit effectiveness. Moreover, Mekelle (2017) had measured internal audit effectiveness by using high or low performance. This proxy is not a strong measurement relative to other measurements because it leads the respondents to incline into one direction.

There might be many factors which might probability measure internal auditing practices and effectiveness. But, for this study 9 internal auditing practices variables and 3 internal audit effectiveness variables were taken. With this understanding, therefore, the operational definition of the study regarding the internal auditing practices and internal audit effectiveness is presented in Table 1.

\subsection{Research Framework}

A mixed research design employing both descriptive and explanatory was used. In accordance with the Ministry of Science and Higher education-Ethiopia, based on the year in which they were established, public higher education institutions are classified into three strata, i.e. first-generation universities, second-generation universities, and third-generation universities (Zerihun, Personal Communication, September 25, 2017). In this particular study, the sample institutions were selected by considering these strata. With regards to the sampling techniques employed towards achieving the objective of the study, proportional stratified random sampling, purposive sampling and census were used for the selection of sample institutions, the relevant department and the appropriate respondents respectively. Following this, because they were few in numbers, all internal auditors of the sample universities were included as respondents, i.e. a total of one hundred sixty (160) questionnaires were distributed to the internal auditors of the sampled public higher education institutions out of which one hundred twenty-one (121) questionnaires were covered after editing. The internal auditors were picked from eighteen sample universities, out of the 30 target universities. Eighteen sample universities were selected by taking into account the following points: First, the universities are located in different regions of the country due to this taking the whole institutions is costly and also it's difficult to manage; and second, the institutions are similar in policies, procedures, internal audit manual, rules and regulations, as well as in organizational structure. As a result of this, it is possible to say this sample size could be represented the whole 
Table 1. Definitions of measures of variables.

\begin{tabular}{|c|c|}
\hline Construct & Definition of Measure \\
\hline Top management support & $\begin{array}{l}\text { The support of the management regarding the training and development of internal auditors, the response of the } \\
\text { management for audit findings and audit recommendations, and the cooperation of the management for the } \\
\text { internal auditors. }\end{array}$ \\
\hline Organizational independence & $\begin{array}{l}\text { The freedom of the internal auditors to include any audit findings in the audit reports, the relationships of the } \\
\text { internal audit department with the management team of the university, the freedom of the internal auditors } \\
\text { regarding the accessibility of information or data pools while they run the audit activities, and the content of the } \\
\text { annual work plan of the internal audit with respect to financial budget and staffing information. }\end{array}$ \\
\hline $\begin{array}{l}\text { Adequate and competent } \\
\text { internal auditors }\end{array}$ & $\begin{array}{l}\text { The size, recruitment policy, training and development programs, education level and experience of internal } \\
\text { auditors. }\end{array}$ \\
\hline Internal audit charter & $\begin{array}{l}\text { A formal written document, which contains the scope, purpose, authority, and responsibility of internal auditors } \\
\text { in the institution. }\end{array}$ \\
\hline Quality of internal audit work & $\begin{array}{l}\text { The determiner of the annual audit plan, the coverage of audit, the follow-up procedure, the applicability of laws, } \\
\text { regulations, policies and procedures, the discussion of internal auditors and auditees about the audit findings } \\
\text { before the final audit reports are issued, and the reliability of audit working paper. }\end{array}$ \\
\hline Career and advancement & $\begin{array}{l}\text { Hiring and assigning employees for temporary as an internal auditor to transfer them to a better position in the } \\
\text { near future. }\end{array}$ \\
\hline $\begin{array}{l}\text { Management perception of } \\
\text { internal audit function value }\end{array}$ & Managers' awareness or understanding regarding the internal auditors' roles. \\
\hline Information technology & $\begin{array}{l}\text { Usage of software by the internal audit department, and knowledge and skill of internal auditors related to } \\
\text { computerized information systems or software packages. }\end{array}$ \\
\hline Objectivity of internal auditors & $\begin{array}{l}\text { The unbiased mental attitude of internal auditors when carrying out their duties. That is, not participating in an } \\
\text { audit of activities for the operation of which they were responsible previously until a reasonable time has elapsed, } \\
\text { rotating their assignments, and they must be free from social pressure, economic advantage, and political } \\
\text { influence, when performing their audit duties }\end{array}$ \\
\hline Internal audit effectiveness & $\begin{array}{l}\text { Measured by three dimensions: Auditees' evaluation (the evaluation of the management regarding the internal } \\
\text { audit reports, and the satisfaction of the management with respect to the work of the internal audit), added } \\
\text { contribution of internal audit (the benefits and savings of internal audits to the institution compared to its costs), } \\
\text { and auditing quality (the constructiveness of the internal audit findings and recommendations, the applicability of } \\
\text { the internal audit recommendations, and the level or way of identifying risks while the audit activities are } \\
\text { performed). }\end{array}$ \\
\hline
\end{tabular}

Note: Data for variables were collected on a five-point Likert-type scale and transformed into dummy variable to make suitable for Ch-Square analysis. Dummy variables were formed based on the positive responses: strongly agree and agree as " 1 ", whereas strongly disagree and disagree as "0". Neutral responses were included in "0" because it is slightly negative and it was not taken as positive answers in the analysis.

population. In line with these ideas, Anderson et al. (2011) stated that taking the whole population as a sample of the study may lead to additional cost and also it's difficult to manage. In addition, Kothari (2004), Anderson et al. (2011), and Gebregziabher (2009) stated that too large and too small a sample size is not advisable instead it should be optimum. An optimum sample is a sample that fulfils the following four criteria i.e. representativeness, flexibility, efficiency, and reliability. On the other hand, researchers must consider population variance to take a large or small sample size i.e. a large variance of the population usually needs a large sample size or small variance of the population needs a small sample size, and costs also should take into consideration to select sample size. The respondents were considered based on their direct attachment to the study area. Data were collected from April 2018 to December 2018 for 9 months. By using 
the Analysis of Moment Structures (AMOS), the confirmatory factor analysis was applied to identify a set of items that are strongly related to unobservable variables. Moreover, Pearson Chi-Square test was used to compare the internal auditing practices and effectiveness among the institutions. The hypothesized confirmatory factor analysis models are presented in Figure 1 and Figure 2.

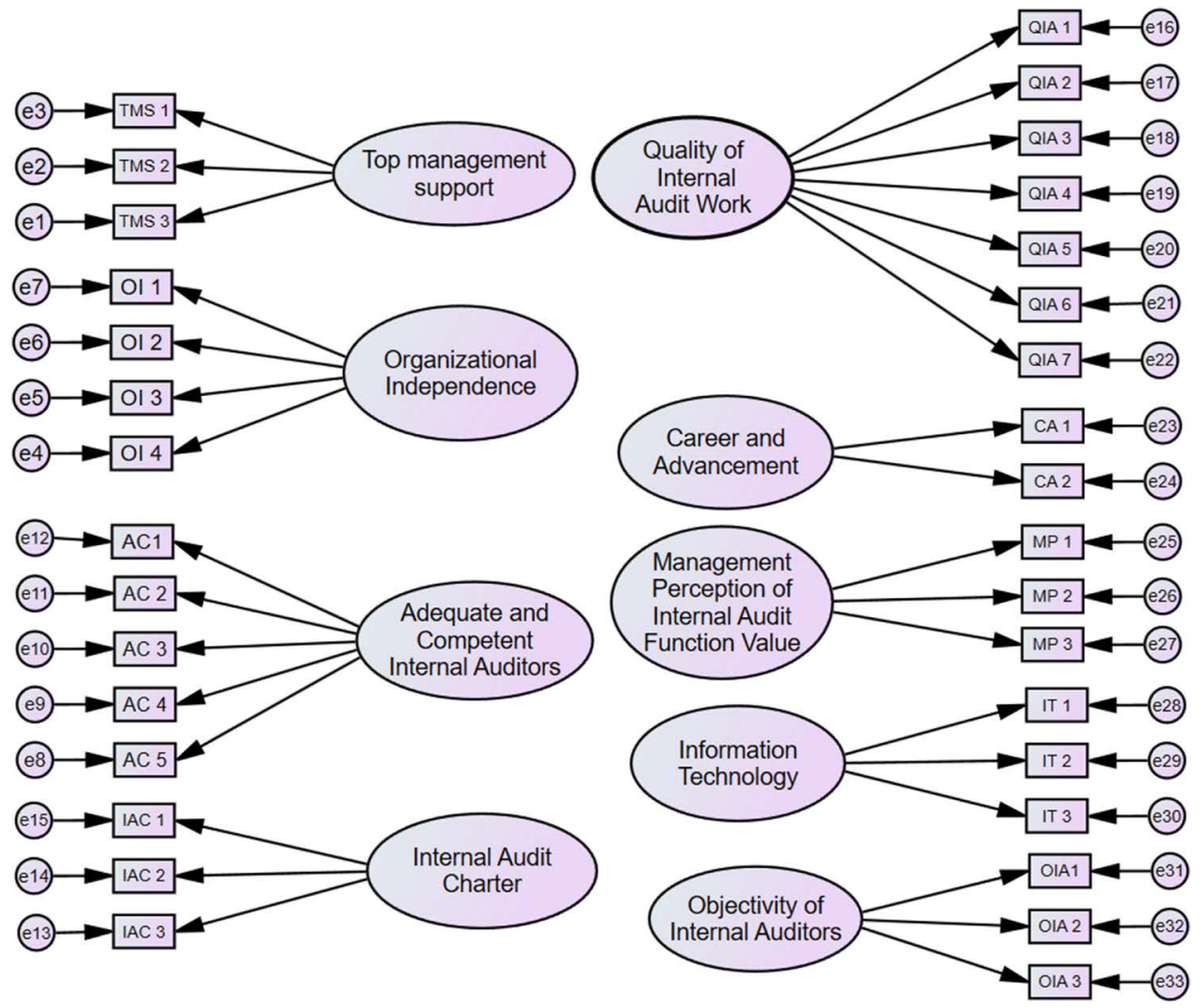

Whereas, "top management support, organizational independence, adequate and competent internal auditors, internal audit charter, quality of internal audit work, career and advancement, management perception of internal audit function value, information technology, and objectivity of internal auditors" refers to unobservable variables or latent variables, " $e$ " is unique factor or unique unobservable variable, and the remaining are items or questions under each latent variable.

Figure 1. Hypothesized confirmatory factor analysis model for nine latent internal auditing practices measure variables with observed variables each.
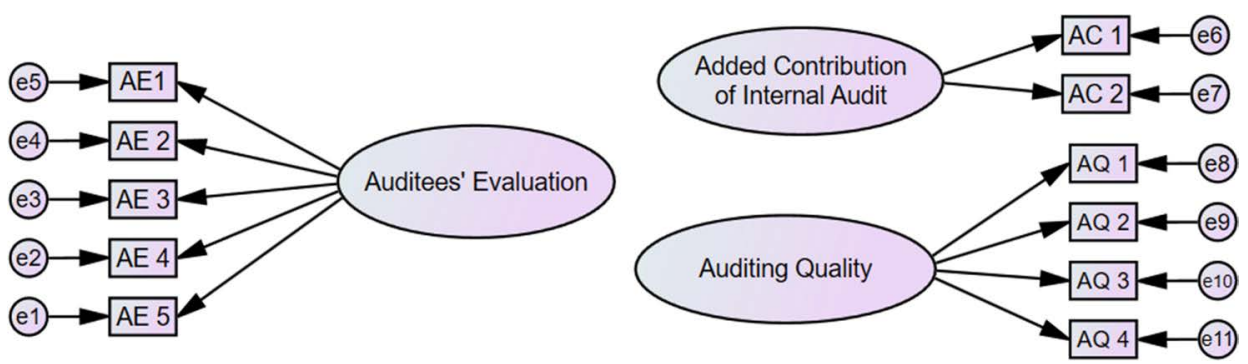

Whereas, "auditees' evaluation, added contribution of internal audit and auditing quality", refers to unobservable variables or latent variables, " $\mathrm{e}$ " is unique factor or unique unobservable variable, and the remaining are items or questions under each latent variable.

Figure 2. Hypothesized confirmatory factor analysis model for three latent internal audit effectiveness measure variables with observed variables each. 


\subsection{Reliability and Validity}

To ensure the reliability and validity of the study, four main points have been done: First, three professionals from disciplines related to the study area have checked the instruments of study; second, most variables of the study were measured by three or more items, which are derived from prior literature of (Cohen \& Sayag, 2010; Deribe \& Regasa, 2014; Ebissa, 2015; Dellai \& Omri, 2016), and international institution of (Institute of Internal Auditors-Global); third, a pilot study was made using the test-retest method with the nine internal auditors of the sample institutions; and fourth, Cronbach's alpha had been applied to measure the internal consistency of the study items. Then, minor modifications were made for the sake of clarity and preciseness of the questions. The reliability of the survey questionnaires for various items varied from 0.797 to 0.865 , i.e. found to be acceptable on the basis of (Ali Alflahat, 2017; Mihret, 2010) (see Table 2).

\subsection{Ethical Concerns}

The questionnaire was fully anonymous not to expose the subjects regarding the information they provide to the study. Therefore, the subjects in the questionnaire or any other issues in the entire study remain confidential. Institutionally, in the subject's response and gender issues as well, no misinterpreting was made, all are respectfully made. Moreover, all materials are properly acknowledged and cited.

\section{Results and Discussion}

\subsection{Results of Confirmatory Factor Analysis}

The survey data of internal auditors were analyzed using the confirmatory factor analysis tool after the threshold model fit indices (relative/normed Chi-Square $\left(\chi^{2} / \mathrm{df}\right)$, Standardized Root Mean Square Residual (SRMR), Root Mean Square Error of Approximation (RMSEA), Goodness-of-Fit Statistic (GFI), Non-Normed Fit Index/Tucker-Lewis Index (NNFI/TLI) and Comparative Fit Index (CFI)) was fulfilled to identify the set of items that are strongly related to the factors or variables. Therefore, seven proxy measures of internal auditing practices from

Table 2. Reliability statistics.

\begin{tabular}{cc}
\hline \multicolumn{1}{c}{ Scale Reliability } \\
\hline Variable & Cronbach's Alpha \\
\hline Organizational independence & 0.803 \\
Adequate and competent internal audit staffs & 0.822 \\
Quality of internal audit work & 0.865 \\
Auditees' evaluation & 0.833 \\
Audit quality & 0.797 \\
\hline
\end{tabular}

Source: Field Survey. 
the nine hypothesized proxy measures of internal auditing practices and two proxy measures of internal audit effectiveness from the three hypothesized proxy measures of internal audit effectiveness were supported by the confirmatory factor analysis. The seven supported proxy measures of internal audit practices are: top management support (significantly explained only by one item from the hypothesized model of three items), organizational independence (significantly explained by all items from the hypothesized model), adequate and competent internal auditors (significantly explained only by three items from the hypothesized model of five items), internal audit charter (significantly explained only by one item from the hypothesized model of three items), quality of internal audit work (significantly explained only by five items from the hypothesized model of seven items), information technology (significantly explained only by one item from the hypothesized model of three items) and objectivity of internal auditors (significantly explained only by one item from the hypothesized model of three items). On the other hand, the two supported proxy measures of internal audit effectiveness are auditees' evaluation (significantly explained only by four items from the hypothesized model of five items) and auditing quality (significantly explained only by three items from the hypothesized model of four items). But the remaining two proxy measures of internal auditing practices, i.e. career and advancement and management perception of internal audit function value, and one proxy measure of internal audit effectiveness, i.e. the added contribution of internal audit were not significantly explained by any item from the hypothesized model.

Thus, from this understanding, in the study, only the seven supported proxy measures of internal auditing practices, i.e. top management support, organizational independence, adequate and competent internal auditors, internal audit charter, quality of internal audit work, information technology and objectivity of internal auditors, and two proxy measures of internal audit effectiveness, i.e. auditees' evaluation and auditing quality were used for further analysis to compare internal audit practice and effectiveness among the public higher education institutions. The summary of the variables and items regarding the confirmatory factor analysis results is presented in Table 3.

\subsection{Characterization of the Sample Respondents}

Table 4 signifies that the majority of respondents were male (67.80\%). The majority of the respondents were found to be in the age group of 30 - 50 years (60.30\%). $71.90 \%$ of the respondents were from the accounting field and $78.50 \%$ of the respondents hold a Bachelor's degree. Moreover, the majority of the respondents had from 5 - 10 years $(43.00 \%)$ of work experience related to an internal audit and had no (46.00\%) work experience other than internal auditors.

\subsection{Chi-Square Test Results}

Pearson Chi-Square test was used by using Statistical Package for Social Sciences 
Table 3. Summary of confirmatory factor analysis results.

\begin{tabular}{cccc}
\hline & \multicolumn{2}{c}{ No. of } & \multicolumn{2}{c}{ No. of significant items, Total No. of } \\
Variables & $\begin{array}{c}\text { insignificant } \\
\text { items }\end{array}$ & $\begin{array}{c}\text { or } \\
\text { further analysis }\end{array}$ & $\begin{array}{c}\text { items } \\
\text { tested }\end{array}$ \\
\hline Top management support & 2 & 1 & 3 \\
organizational independence & 0 & 3 & 4 \\
Adequate and competent internal auditors & 2 & 1 & 5 \\
Internal audit charter & 2 & 5 & 3 \\
Quality of internal audit work & 2 & 0 & 7 \\
Career and advancement & 2 & 0 & 2 \\
Management perception of internal & 3 & 1 & 3 \\
audit function value & & 1 & 3 \\
Information technology & 2 & 4 & 5 \\
Objectivity of internal auditors & 2 & 0 & 2 \\
Auditees' evaluation & 1 & 3 & 4 \\
\hline Added contribution of internal audit & 2 & 1 &
\end{tabular}

Source: Field Survey.

Table 4. Characterization of the sample respondents.

\begin{tabular}{ccc}
\hline Characterization of the Sample Respondents & Majority respondents & In percent \\
\hline Gender & Male & 67.80 \\
Age & $30-50$ years & 60.30 \\
Field of study & Accounting & 71.90 \\
Work experience as Internal Auditor & $5-10$ years & 43.00 \\
Work experience other than Internal Auditor & No & 46.00 \\
\hline
\end{tabular}

(SPSS) version 23 to compare the internal auditing practices and effectiveness among the institutions. Nationally as well as internationally, it was very difficult to get a standard number that used as a benchmark to compare internal auditing practices and effectiveness among the public higher education institutions in Ethiopia. As a result, based on the mean scores of the variables, the best practicing or effective generation universities were taken as a benchmark. Mean score was used by prior empirical studies in auditing to compare auditing practices and effectiveness among groups (for example, Wahdan et al., 2006). The results of the Chi-Square analysis are presented as under.

\subsection{Comparison of Internal Auditing Practices among the Public Higher Education Institutions in Ethiopia}

Based on the mean score of the variables, the internal auditing practices among the public higher education institutions in Ethiopia with respect to the seven identified variables are as under. 


\section{1) Top Management Support}

Table 5 shows the generation-wise internal auditing practices regarding the top management support in terms of the Mean scores. The mean score of the third-generation universities was high i.e. 4.31 , followed by a 3.03 and 2.76 mean scores were the second-generation and the third-generation universities respectively. Therefore, the mean score of the third-generation universities was taken as a benchmark to compare internal auditing practices among the public higher education institutions in Ethiopia. The Chi-Square value of 0.282 indicates that there was no significant difference in internal audit practices with regard to top management support between the third-generation universities and first-generation universities. Also, the Chi-Square value of 0.148 shows that there was no significant difference in the internal audit practices with regard to top management support among the third-generation universities and second-generation universities. That means, statistically, there was no significant difference among the public higher education institutions in Ethiopia regarding the response of the President to the implementation of internal audit recommendations.

\section{2) Organizational Independence}

The Mean scores of internal auditing practices with regard to organizational independence among the generations are depicted in Table 6. The highest mean score, i.e. 4.25 was the third-generation universities, followed by a 3.65 mean score was second-generation universities and 3.43 mean score was first-generation universities. Thus, the mean score of the third-generation universities was taken as a benchmark to compare internal auditing practices among the public higher education institutions in Ethiopia. The Chi-Square value of 0.419 implies that there was no significant difference in internal audit practices with regard to organizational independence between the third-generation universities and first-

Table 5. Generation-wise internal audit practice of top management support.

\begin{tabular}{ccccc}
\hline Internal Audit Practice & $\begin{array}{c}\text { Third- } \\
\text { Generation } \\
\text { Universities }\end{array}$ & $\begin{array}{c}\text { First- } \\
\text { Generation } \\
\text { Universities }\end{array}$ & $\begin{array}{c}\text { Third- } \\
\text { Generation } \\
\text { Universities }\end{array}$ & $\begin{array}{c}\text { Second- } \\
\text { Generation } \\
\text { Universities }\end{array}$ \\
\hline Top management support & 4.31 & 2.76 & 4.31 & Mean scores \\
& Chi-Square value $=0.282$ & Chi-Square value $=0.148$ \\
\hline
\end{tabular}

Source: Field Survey.

Table 6. Generation-wise internal audit practice of organizational independence.

\begin{tabular}{ccccc}
\hline Internal Audit Practice & $\begin{array}{c}\text { Third- } \\
\text { Generation } \\
\text { Universities }\end{array}$ & $\begin{array}{c}\text { First- } \\
\text { Generation } \\
\text { Universities }\end{array}$ & $\begin{array}{c}\text { Third- } \\
\text { Generation } \\
\text { Universities }\end{array}$ & $\begin{array}{c}\text { Second- } \\
\text { Generation } \\
\text { Universities }\end{array}$ \\
\hline Organizational independence & 4.25 & 3.43 & Mean scores \\
& Chi-Square value $=0.419$ & Chi-Square value $=0.388$ \\
\hline
\end{tabular}

Source: Field Survey. 
generation universities. The Chi-Square value of 0.388 also indicates that there was no significant difference in the internal audit practices with regard to organizational independence between the third-generation universities and second-generation universities. On the other hand, statistically, there was no significant difference between the public higher education institutions in Ethiopia with respect to the independence of internal auditors while doing their audit activities.

\section{3) Adequate and Competent Internal Auditors}

As Table 7 shows the generation-wise internal auditing practices related to adequate and competent internal auditors in terms of the mean score. The highest mean score, i.e. 4.02 was third-generation universities, followed by a 3.59 mean score was second-generation universities and 2.94 mean score was firstgeneration universities. Hence, the mean score of the third-generation universities was taken as a standard to compare internal auditing practices among the public higher education institutions in Ethiopia. The Chi-Square value of 0.224 implies that there was no significant difference in internal audit practices with regard to adequate and competent internal auditors among the third-generation universities and first-generation universities. The Chi-Square value of 0.675 also shows that there was no significant difference in the internal audit practices with regard to adequate and competent internal auditors between the third-generation universities and second-generation universities. That is, with regard to the adequate and competent internal auditors (recruitment policy, training and development programs, and education status of internal auditors), there was no significant difference among the public higher education institutions in Ethiopia.

\section{4) Internal Audit Charter}

Table 8 indicates the mean scores of the universities regarding the internal audit charter. The highest mean score, i.e. 4.43 was the third-generation university, followed by a 3.68 mean score was the second-generation universities, 3.27 mean score was the first-generation universities. Thus, the mean score of the third-generation universities was taken as a standard to compare the internal auditing practices among the public higher education institutions in Ethiopia. The Chi-Square value of 0.294 implies that there was no significant difference in internal audit practices with regard to internal audit charter among the third-

Table 7. Generation-wise internal audit practice of adequate and competent internal auditors.

\begin{tabular}{ccccc}
\hline Internal Audit Practice & $\begin{array}{c}\text { Third- } \\
\text { Generation } \\
\text { Universities }\end{array}$ & $\begin{array}{c}\text { First- } \\
\text { Generation } \\
\text { Universities }\end{array}$ & $\begin{array}{c}\text { Third- } \\
\text { Generation } \\
\text { Universities }\end{array}$ & $\begin{array}{c}\text { Second- } \\
\text { Generation } \\
\text { Universities }\end{array}$ \\
\hline $\begin{array}{c}\text { Mean scores } \\
\text { internal auditors }\end{array}$ & $\mathbf{4 . 0 2}$ & 2.94 & $\mathbf{4 . 0 2}$ & 3.59 \\
& Chi-Square value $=0.224$ & \multicolumn{2}{c}{ Chi-Square value $=0.675$} \\
\hline
\end{tabular}

Source: Field Survey. 
generation universities and first-generation universities. The Chi-Square value of 0.483 also shows that there was no significant difference in the internal audit practices with regard to internal audit charter between the third-generation universities and second-generation universities. This means that, statistically, there was no significant difference among the public higher education institutions in Ethiopia regarding the performing audit activities in accordance with the internal audit charter.

\section{5) Quality of Internal Audit Work}

The generation-wise mean scores of internal auditing practices with regard to the quality of internal audit work are depicted in Table 9. The highest mean score, i.e. 4.20 was the third-generation universities, followed by 4.07 mean score was the second-generation universities, 3.19 mean score was the first-generation universities. Thus, the mean score of the third-generation universities was taken as a standard to compare internal auditing practices between the public higher education institutions in Ethiopia. The Chi-Square value of 0.388 implies that there was no significant difference in internal audit practices with regard to the quality of internal audit work among the third-generation universities and firstgeneration universities. The Chi-Square value of 0.696 also shows that there was no significant difference in the internal audit practices with regard to the quality of internal audit work between the third-generation universities and second-generation universities. This implies that statistically there was no significant difference in the quality of internal audit work among the public higher education institutions in Ethiopia.

\section{6) Information Technology}

Table 10 shows the mean scores of internal auditing practices related to information technology. The highest mean score, i.e. 3.00 was the first-generation

Table 8. Generation-wise internal audit practice of internal audit charter.

\begin{tabular}{ccccc}
\hline Internal Audit Practice & $\begin{array}{c}\text { Third- } \\
\text { Generation } \\
\text { Universities }\end{array}$ & $\begin{array}{c}\text { First- } \\
\text { Generation } \\
\text { Universities }\end{array}$ & $\begin{array}{c}\text { Third- } \\
\text { Generation } \\
\text { Universities }\end{array}$ & $\begin{array}{c}\text { Second- } \\
\text { Generation } \\
\text { Universities }\end{array}$ \\
\hline Internal audit charter & 4.43 & 3.27 & 4.43 & Mean scores \\
& Mean scores & Chi-Square value $=0.294$ & Chi-Square value $=0.483$ \\
\hline
\end{tabular}

Source: Field Survey.

Table 9. Generation-wise internal audit practice of quality of internal audit work.

\begin{tabular}{ccccc}
\hline Internal Audit Practice & $\begin{array}{c}\text { Third- } \\
\text { Generation } \\
\text { Universities }\end{array}$ & $\begin{array}{c}\text { First- } \\
\text { Generation } \\
\text { Universities }\end{array}$ & $\begin{array}{c}\text { Third- } \\
\text { Generation } \\
\text { Universities }\end{array}$ & $\begin{array}{c}\text { Second- } \\
\text { Generation } \\
\text { Universities }\end{array}$ \\
\hline Quality of internal audit work & 4.2 & 3.19 & 4.20 & 4.07 \\
& Mean scores & Mean scores & Chi-Square value $=0.696$
\end{tabular}

Source: Field Survey. 
universities, followed by 2.94 mean score was the third-generation universities, 2.90 mean score was the second-generation universities. Therefore, the mean score of the first-generation universities was taken as a standard to compare internal auditing practices among the public higher education institutions in Ethiopia. The Chi-Square value of 0.353 implies that there was no significant difference in internal audit practices with regard to information technology among the first-generation universities and third-generation universities. Also, the Chi-Square value of 0.05 or at a 5 percent significance level shows that there was a significant difference in the internal audit practices with regard to information technology between the first-generation universities and second-generation universities. That is, although there was no significant difference between the first-generation universities and third-generation universities with regard to the skills of internal auditors related to information systems or software packages, there was a significant difference between the first-generation universities and second-generation universities.

\section{7) Objectivity of Internal Auditors}

The generation-wise mean scores of internal auditing practices with regard to the objectivity of internal auditors are depicted in Table 11. The highest mean score, i.e. 4.17 was the third-generation universities, followed by a 3.80 mean score was the first-generation universities, 3.68 mean score was the second-generation universities. Thus, the mean score of the third-generation universities was taken as a standard to compare internal auditing practices between the public higher education institutions in Ethiopia. The Chi-Square value of 0.365 implies that there was no significant difference in internal audit practices with regard to the objectivity of internal auditors among the third-generation

Table 10. Generation-wise internal audit practice of information technology.

\begin{tabular}{lcccc}
\hline Internal Audit Practice & $\begin{array}{c}\text { Third- } \\
\text { Generation } \\
\text { Universities }\end{array}$ & $\begin{array}{c}\text { First- } \\
\text { Generation } \\
\text { Universities }\end{array}$ & $\begin{array}{c}\text { First- } \\
\text { Generation } \\
\text { Universities }\end{array}$ & $\begin{array}{c}\text { Second- } \\
\text { Generation } \\
\text { Universities }\end{array}$ \\
\hline Information technology & 2.94 & 3.00 & 3.00 & Mean scores \\
Chi-Square value $=0.353$ & Chi-Square value $=0.05^{* *}$
\end{tabular}

Source: Field Survey. ${ }^{*}$ Significant at $5 \%$ level.

Table 11. Generation-wise internal audit practice of objectivity of internal auditors.

\begin{tabular}{ccccc}
\hline Internal Audit Practice & $\begin{array}{c}\text { Third- } \\
\text { Generation } \\
\text { Universities }\end{array}$ & $\begin{array}{c}\text { First- } \\
\text { Generation } \\
\text { Universities }\end{array}$ & $\begin{array}{c}\text { Third- } \\
\text { Generation } \\
\text { Universities }\end{array}$ & $\begin{array}{c}\text { Second- } \\
\text { Generation } \\
\text { Universities }\end{array}$ \\
\hline Objectivity of internal auditors' & 4.17 & 3.80 & Mean scores \\
& Chi-Square value $=0.365$ & Chi-Square value $=0.68$ \\
\hline
\end{tabular}

Source: Field Survey. 
universities and first-generation universities. Also, the Chi-Square value of 0.68 shows that there was no significant difference in the internal audit practices with regard to the objectivity of internal auditors between the third-generation universities and second-generation universities. On the other side, it reveals that there was no significant difference between the public higher education institutions in Ethiopia with respect to the periodic assignment rotation within the internal auditors.

\subsection{Comparison of Internal Audit Effectiveness among the Public Higher Education Institutions in Ethiopia}

Based on the mean scores of the variables, the internal audit effectiveness among the public higher education institutions in Ethiopia related to the two identified variables i.e. auditees' evaluation and auditing quality are presented here under.

\section{1) Auditees' Evaluation}

Table 12 shows the internal audit effectiveness with regard to auditees' evaluation dimension in Ethiopian public higher education institutions in terms of the mean score. The highest mean score, i.e. 4.16 was the third-generation universities, followed by 3.59 mean score was the second-generation universities and 3.24 mean score was the first-generation universities. Thus, the mean score of the third-generation universities was taken as a standard to compare internal audit effectiveness between the public higher education institutions in Ethiopia. The Chi-Square value of 0.811 implies that there was no significant difference in internal audit effectiveness with regard to the auditees' evaluation between the third-generation universities and first-generation universities. Also, the Chi-Square value of 0.389 indicates that there was no significant difference in the internal audit effectiveness with regard to the auditees' evaluation between the third-generation universities and second-generation universities. That is, this finding indicates that statistically from the auditees' evaluation dimension, there was no internal audit effectiveness difference among the public higher education institutions in Ethiopia.

\section{2) Auditing Quality}

The generation-wise mean scores of internal audit effectiveness with regard to the auditing quality dimension is depicted in Table 13. The highest mean score, i.e. 4.34 was the third-generation university, followed by a 3.78 mean score was the second-generation universities, 3.43 mean score was the first-generation

Table 12. Generation-wise internal audit effectiveness of auditees' evaluation.

\begin{tabular}{ccccc}
\hline Internal Audit Effectiveness & $\begin{array}{c}\text { Third- } \\
\text { Generation } \\
\text { Universities }\end{array}$ & $\begin{array}{c}\text { First- } \\
\text { Generation } \\
\text { Universities }\end{array}$ & $\begin{array}{c}\text { Third- } \\
\text { Generation } \\
\text { Universities }\end{array}$ & $\begin{array}{c}\text { Second- } \\
\text { Generation } \\
\text { Universities }\end{array}$ \\
\hline Auditees' Evaluation & 4.16 & 3.24 & 4.16 & 3.59 \\
& Chi-Square value $=0.811$ & Mean scores \\
\end{tabular}

Source: Field Survey. 
Table 13. Generation-wise internal audit effectiveness of auditing quality.

\begin{tabular}{ccccc}
\hline Internal Audit Effectiveness & $\begin{array}{c}\text { Third- } \\
\text { Generation } \\
\text { Universities }\end{array}$ & $\begin{array}{c}\text { First- } \\
\text { Generation } \\
\text { Universities }\end{array}$ & $\begin{array}{c}\text { Third- } \\
\text { Generation } \\
\text { Universities }\end{array}$ & $\begin{array}{c}\text { Second- } \\
\text { Generation } \\
\text { Universities }\end{array}$ \\
\hline Auditing quality & \multicolumn{2}{c}{ Mean scores } & \multicolumn{2}{c}{ Mean scores } \\
& $\mathbf{4 . 3 4}$ & 3.43 & 4.34 & 3.78 \\
& Chi-Square value $=0.849$ & \multicolumn{2}{c}{ Chi-Square value $=0.247$} \\
\hline
\end{tabular}

Source: Field Survey.

universities. Thus, the mean score of the third-generation universities was taken as a standard to compare internal audit effectiveness among the public higher education institutions in Ethiopia. The Chi-Square value of 0.849 implies that there was no significant difference in internal audit effectiveness with regard to the auditing quality between the third-generation universities and first-generation universities. Moreover, the Chi-Square value of 0.247 implies that there was no significant difference in the internal audit effectiveness with regard to the auditing quality between the third-generation universities and second-generation universities. To be precise, statistically, from the auditing quality point of view, there was no significant internal audit effectiveness difference between the public higher education institutions in Ethiopia.

\section{Conclusion}

The Pearson Chi-Square test was applied to compare the internal auditing practices and effectiveness among the public higher education institutions in Ethiopia. The result revealed that out of the seven supported internal auditing proxy measures variables in the confirmatory factor analysis, only regarding the information technology (the skills of internal auditors related to information systems or software packages), there was a significant difference at a 5 percent confidence level between the first-generation universities and the second-generation universities. On the other hand, regarding the top management support (the response of the President to the implementation of internal audit recommendations), organizational independence, adequate and competent internal auditors, internal audit charter (performing audit activities in accordance with the internal audit charter), quality of audit work and objectivity of internal auditors (the periodic assignment rotation within the internal auditors), there was no significant difference in internal auditing practices among the public higher education institutions. Moreover, the study findings revealed that from the auditees' evaluation and auditing quality dimensions, statistically there was no significant internal audit effectiveness difference among the public higher education institutions.

Generally, statistically, there was no significant difference in internal auditing practices and effectiveness among the public higher education institutions in Ethiopia. The following could be the reasons for this insignificant difference: First, most public higher education institutions in Ethiopia are similar in poli- 
cies, procedures, and organizational contexts; second, all the public higher education institutions share the same internal audit manual; third, all the public higher education institutions are governed by the same rules and regulations; and fourth, all the public higher education institutions have the same organizational structure.

\section{Recommendations}

Based on the study findings, the researchers would like to forward the following recommendations. The Ministry of Finance and Economic Cooperation in collaboration with the Presidents of Ethiopian public higher education institutions should encourage the internal audit department of Ethiopian public higher education institutions to use electronic technology or modern auditing system instead of traditional auditing systems to improve the auditing activities of the institutions. This could be done by improving the knowledge and skill of internal auditors related to computerized information systems. The knowledge and skill of internal auditors related to computerized information system can improve by making experience share with other similar institutions like from the first-generation universities because according to the finding of this study, the internal auditors of the first-generation universities were possessed enough skills with regard to computerized information systems or software packages relative to the second and third-generation universities, by giving appropriate training, by allocating appropriate education and training budgets, by making linkage with trainers' institutions (like Institute of Internal Auditors-Ethiopia, Accounting and Auditing Board of Ethiopia, Office of the Federal Auditor General of Ethiopia, etc.), by hiring adequate internal auditors based on the institutions' internal audit task loads, and by encouraging to exist a good professional relationship between internal and external auditors. Fadzil and Hanim (2003), and Mohamud (2013) stated that in ancient time the major operation of the internal auditor was making an oral report to the responsible person, but at a current time, sophisticated electronic technology is required to give timely information for the users to make their appropriate decisions regarding the global operations.

\section{Contributions of the Study}

\subsection{Contribution to the Literature}

Although the significance of internal audit has increased in developing countries, most prior studies related to internal audit effectiveness have been conducted on developed countries (Eden \& Moriah, 1996; Deribe \& Regasa, 2014; Cohen \& Sayag, 2010; Dellai \& Omri, 2016). Therefore, conducting this study in this developing country gives an additional insight for empirical literature for other developing countries.

\subsection{Contribution to Practice}

The study uses institutions particularly Ethiopian public higher education insti- 
tutions to understand the internal auditing practices and internal audit effectiveness. On the other hand, members of corporate governance such as audit committees, the board of directors' etc., shall take the findings of this study into account to better equip internal audit functions and corporate governance effectiveness. Moreover, Ethiopia is one of the developing countries in which internal audit practice is not yet sufficiently explored (Mihret, 2010). Mihret and Yismaw (2007) conducted a study in Ethiopia public sector to assess the internal audit effectiveness by triangulating internal audit practices of the institutions and some set of universal standards. Generally, their findings indicate that the numbers of actual audits performed in a given period were usually less than the number of audits stated in the annual audit plan. This implies that there is a problem with respect to audit practice in the Ethiopian public sector. Besides to Mihret and Yismaw (2007), Mihret and Woldeyohannis (2008) conducted a study in Ethiopian state owned enterprise to examine the role of internal audit department on value-adding. Their findings indicated that there was a relatively better internal audit practice in Ethiopia. Therefore, their findings are a clue for further research to prove the current internal audit practice of the Ethiopia public sectors in general and particularly the Ethiopia public higher education institutions. On the other hand, the study would use to understand to what extent internal auditing practice is being performed and developed largely at a nation and particularly in the Ethiopian public higher education institutions, which enables to compare the current status of internal audit in Ethiopia with reference to the profession of the global picture. In addition, it informs the key priorities of the development of internal audit as a profession to the Institute of Internal Auditors-Global and the Institute of Internal Auditors-Ethiopia.

\section{Future Scope}

The researchers suggest further research to improve the findings by minimizing the limitations of the study. Particularly, the researchers suggest future research be conducted on the followings: First, Cohen and Sayag (2010) stated that the common method error often occurs if the data are collected from the same source. For this study, the data were collected from the same source, i.e. only from the internal auditors of the Ethiopian public higher education institutions. Thus, if the data will be collected from the President/management in addition to the internal auditors, especially, to measure internal audit effectiveness, it will be a potential area for future studies, and second, the study focused on the internal auditing practices and effectiveness among the public higher education institutions in Ethiopia. On the other hand, it does not cover the effect of internal auditing practices on internal audit effectiveness. Therefore, by taking into account the variables stated in this study and in others, using the appropriate model like the structural equation model, checking the effect of internal auditing practices on internal audit effectiveness is another potential area for future research. Regarding this model, Cangur and Ercan (2015) stated that if there is a latent vari- 
able within one study, using structural equation model are more preferable.

\section{Funding Statement}

For this study, from funding agencies, commercial, public, or not-for-profit sectors, not any specific grant was given.

\section{Conflicts of Interest}

The authors declared no conflict of interest.

\section{References}

Abu-Musa, A. A. (2008). Information Technology and its Implications for Internal Auditing: An Empirical Study of Saudi Organizations. Managerial Auditing Journal, 23, 438-466. https://doi.org/10.1108/02686900810875280

Adams, M. B. (1994). Agency Theory and the Internal Audit. Managerial Auditing Journal, 9, 8-12. https://doi.org/10.1108/02686909410071133

Ali Alflahat, M. T. (2017). The Impact of Internal Audit on Organizational Performance of Selected Jordanian Companies. International Journal of Multidisciplinary Research and Development, 4, 285-289.

Al-Khaddash, H., Al Nawas, R., \& Ramadan, A. (2013). Factors Affecting the Quality of Auditing: The Case of Jordanian Commercial Banks. International Journal of Business and Social Science, 4, 206-222.

Al-Matari, E. M., Al-Swidi, A. K., \& Fadzil, F. H. B. (2014). The Effect of the Internal Audit and Firm Performance: A Proposed Research Framework. International Review of Management and Marketing, 4, 34-41.

Al-Refaee, K., \& Saim, A. (2013). The Effect of Using Information Technology Increasing the Efficiency of Internal Auditing Systems in Islamic Bank Operating in Jordan. Research Journal of Finance and Accounting, 4, 2222-2847.

Anderson, D. R., Sweeney, D. J., \& Williams, T. A. (2011). Essentials of Statistics for Business and Economics (6th ed.). Boston, MA: South-Western Cengage Learning.

Arens, A. A., Elder, R. J., \& Mark, B. (2012). Auditing and Assurance Services: An Integrated Approach (14th ed.). Boston: Prentice Hall.

Asechemie, D. P. (1997). African Labour Systems, Maintenance Accounting and Agency Theory. Critical Perspectives on Accounting, 8, 373-392.

https://doi.org/10.1006/cpac.1996.0121

Baharud-din, Z., Shokiyah, A., \& Ibrahim, M. S. (2014). Factors That Contribute to the Effectiveness of Internal Audit in Public Sector. International Proceedings of Economics Development and Research, 70, 126-132.

Barley, S. R., \& Tolbert, P. S. (1997). Institutionalization and Structuration: Studying the Link between Action and Institution. Organization Studies, 18, 93-117.

https://doi.org/10.1177/017084069701800106

Cangur, S., \& Ercan, I. (2015). Comparison of Model Fit Indices Used in Structural Equation Modeling under Multivariate normality. Journal of Modern Applied Statistical Methods, 14, 152-167. https://doi.org/10.22237/jmasm/1430453580

Cohen, A., \& Sayag, G. (2010). The Effectiveness of Internal Auditing: An Empirical Examination of Its Determinants in Israeli Organisations. Australian Accounting Review, 20, 296-307. https://doi.org/10.1111/j.1835-2561.2010.00092.x 
Dellai, H., \& Omri, M. A. B. (2016). Factors Affecting the Internal Audit Effectiveness in Tunisian Organizations. Research Journal of Finance and Accounting, 7, 208-211.

Deribe, W. J., \& Regasa, D. G. (2014). Factors Determining Internal Audit Quality: Empirical Evidence from Ethiopian Commercial Banks. Research Journal of Finance and Accounting, 5, 86-94.

DiMaggio, P. J. \& Powell, W. W. (1983). The Iron Cage Revisited: Institutional Isomorphism and Collective Rationality in Organizational Fields. American Sociological Review, 48, 147-160. https://doi.org/10.2307/2095101

Ebissa, T. (2015). Determinants of Internal Auditors Effectiveness: Case of Ethiopian Public Sectors. International Journal of Advances in Management and Economics, 4, 73-83.

Eden, D., \& Moriah, L. (1996). Impact of Internal Auditing on Branch Bank Performance: A Field Experiment. Organizational Behavior and Human Decision Processes, 68, 262-271. https://doi.org/10.1006/obhd.1996.0104

Ethiopian News Agency Report (n.d.). https://www.awrambatimes.com/?p=13861

Fadzil, H., \& Hanim, F. (2003). Internal Auditing Practices and Performance of Internal Audit Department. Doctoral Dissertation, Malaysia: University Sains Malaysia.

Fekadu, B. (2009). Internal Audit Practices: A Case of Ethiopian Governmental Higher Educational Institutions. Master's Thesis, Ethiopia: Addis Ababa University. http://etd.aau.edu.et/bitstream/handle/123456789/2882/Bethlehem\%20Fekadu.pdf?sequ

Gebregziabher, H. G. (2009). Research Methods and Analysis for Business Studies: A Holistic Approach. Saarbrücken: VDM Verlag Dr. Müller.

Goodwin, J., \& Yeo Y. T. (2000). Two Factors Affecting Internal Audit Independence and Objectivity: Evidence from Singapore. International Journal of Auditing, 5, 107-125. https://doi.org/10.1111/j.1099-1123.2001.00329.x

Haron, H., Chambers, A., Ramsi, R., \& Ismail, I. (2004). The Reliance of External Auditors on Internal Auditors. Managerial Auditing Journal, 19, 1148-1159. https://doi.org/10.1108/02686900410562795

Hung, J. H., \& Han, H. L. (1998). An Empirical Study on Effectiveness of Internal Auditing for Listed Firms in Taiwan.

http://citeseerx.ist.psu.edu/viewdoc/download?doi=10.1.1.200.6274\&rep=rep1\&type=pdf

Institute of Internal Auditors IIA (2001). Standards for the Professional Practice of Internal Auditing. Altamonte Springs, FL: The Institute of Internal Auditors.

http://www.theiia.org/iia/index.cfm

Institute of Internal Auditors IIA (2004). The Role of Internal Audit in Enterprise-Wide Risk Management. Altamonte Springs, FL: Institute of Internal Auditors.

http://www.theiia.org/guidance/standards-and-practices/positionpapers/current-positi on-papers

Institute of Internal Auditors IIA (2012). International Standards for the Professional Practice of Internal Auditing (Standards). Altamonte Springs, FL: Institute of Internal Auditors.

Kothari, C. R. (2004). Research Methodology: Methods and Techniques (2nd ed.). India: New Age International Publishers.

Mekelle, D. B. I. (2017). Assessment of the Effectiveness of Internal Auditing Performance: A Case Study of Selected Branches of Dashen Bank in Mekelle. Master's Thesis, Ethiopia: Micro-Link Information Technology and Business College.

https://www.academia.edu/36596083/ 
Mihret, D. G. (2010). Antecedents and Organizational Performance Implication of Internal Audit Effectiveness: Evidence from Ethiopia. Doctoral Dissertation, Toowoomba: University of Southern Queensland. https://www.researchgate.net/publication/277158506

Mihret, D. G., \& Woldeyohannis, G. Z. (2008). Value-Added Role of Internal Audit: An Ethiopian Case Study. Managerial Auditing Journal, 23, 567-595. https://doi.org/10.1108/02686900810882110

Mihret, D. G., \& Yismaw, W. A. (2007). Internal Audit Effectiveness: An Ethiopian Public Sector Case Study. Managerial Auditing Journal, 22, 470-484. https://doi.org/10.1108/02686900710750757

Mohamud, H. A. (2013). Internal Auditing Practices and Internal Control System in Somali Remittance Firms. International Journal of Business and Social Science, 4, 165-172.

Paape, L. (2007). Corporate Governance: The Impact on the Role, Position, and Scope of Services of the Internal Audit Function (No. 111). Doctoral Dissertation, Erasmus Research Institute of Management, RSM Erasmus University, Erasmus University Rotterdam. https://repub.eur.nl/pub/10417/EPS2007111MKT9058921437PAAPE.pdf

Pickett, K. S. (2005). The Essential Handbook of Internal Auditing (2nd ed.). Chichester: John Wiley \& Sons, Ltd.

Pickett, K. S. (2010). The Internal Auditing Handbook (3rd ed.). Chichester: John Wiley \& Sons, Ltd.

Sakour, A. S., \& Laila, N. H. B. (2015). Internal Audit Effectiveness in Libyan Public Enterprises: An Approach to the Development of a Theoretical Framework. Global Business \& Management Research, 7, 12-18.

Spraakman, G. (1997). Transaction Cost Economics: A Theory of Internal Audit. Managerial Auditing Journal, 17, 323-330. https://doi.org/10.1108/02686909710180670

Trines, S. (2018). Education in Ethiopia. Education System Profiles. World Education News + Reviews. https://wenr.wes.org/2018/11/education-i

Wahdan, M. A., Spronck, P., Ali, H. F., \& Vaassen, E. (2006). Auditing in Egypt: Diagnoses and Remedies by Two Groups. Partners' Conference, Netherlands. 